\title{
Terrorism in Contemporary Era Narration
}

\author{
Rashad Mohammed Moqbel Al Areqi ${ }^{1}$ \\ ${ }^{1}$ English Department, Faculty of Sciences and Arts, Al Mandaq, Albaha University, Saudi Arabia \\ Correspondence: Rashad Mohammed Moqbel Al Areqi, English Department, Faculty of Sciences and Arts, Al \\ Mandaq, Albaha University, Saudi Arabia. E-mail: alarikirashad@yahoo.com
}

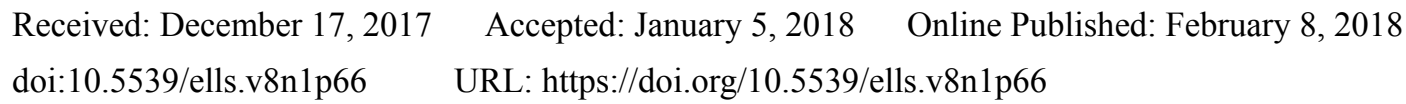

\begin{abstract}
Terrorism is the talk of the world. It also occupies a larger part in the media and Islam receives relatively high attention compared to other religions. Islam, Muslims, particularly Arabs, in the eyes of the West, become the source of terrorism that gives the West an opportunity to launch a war against the countries which are accused of terrorism. It is, in fact, a war against radical Islam as they claimed. How do the western politicians, reporters, journalists and writers address terrorism in their official speech or literary works that reflect their vision and understanding of terror/terrorism? The present article addresses Amy Waldman's The Submission, 2011, John Updike's Terrorist, 2006, Joel Rosenberg's The Last Jihad, 2002, and their vision of terrorism, its reasons and the people behind. The article concluded that the western narratives written during the controversial period of the post 9/11. 2001 came deeply influenced by the western media reports and the official statements about 9/11. Such narratives also created, but enrooted Islamophobia and anti- Muslim attitudes in the hearts of the westerners while the western narratives written lately showed more sympathy and rationality towards Muslim characters because the hidden facts of terrorism become exposed. The narratives showed that the western countries exaggerate in their reactions against terrorists/terrorism and the present research concluded that the West has taken precautionary steps to protect its interests and its allies in such countries accused of terrorism. The westerners make use of their domination upon the media to create negative and aggressive attitudes towards Islam/Muslims to blackmail the Islamic countries in the name of war on terrorism, and to secularize/westernize the different aspects of life in such Islamic countries. The narratives showed that war on terrorism is a war on Islam, particularly, radical Islam as claimed.
\end{abstract}

Keywords: terrorism, Islam, terrorist, media, culture, religion, west, Muslim, politics

\section{Introduction}

Terrorism is defined by some countries/politicians in a way that keeps their interests, thrones, and reign forever, only for them and their dynasties. The governments, particularly Arabs ones, see in opposition parties and revolutions as terrorist movements which require to be confronted. It becomes easy for the countries, particularly the powerful ones post of 9/11, 2001 to release a claim of terrorism against the peoples or organizations or countries that stand against their own interests, whatever their entity: a country or as an organization or as a leader for one of a terrorist organization as late Osama bin Laden, the leader of Al Qaeda Movement.

Many countries have released accusations to other entities/ countries and other organizations because of the violence directed to such countries which sometimes could be a reaction for another sort of violence. No wonder to find Israel accuses Hamas Movement of terrorism and Hamas accuses Israel of terrorism, American accuses Afghanistan of terrorism and vice versa and the Arab governments claim that the uprisings and revolutions under the Arab Spring, as called, are a sort of terrorism because they see in such uprisings/revolutions a threat to their own interests as governments so that no doubt the Arab countries may request external help to silence the revolutions and rebellions in their countries in the name of confronting terrorism whatever the damage could be occurred to the place and the people as long as their interests and governments are secured. That is clear in countries such as Syria, Yemen, Libya, and Egypt...etc. For such countries, the important thing is how to keep their interests safe and their governments secured.

Most of western countries have agreement that the Islam/Muslims are the source of terrorism and they have pointed the finger of accusation to Islamic /Arab Countries under the claim that most of violent and terrorist actions attributed to Muslims regardless of their nationalities. America and the West have accused Muslims and 
Arabs of the violent action that has destroyed the World Trade Center in America in 9/11/2001. Later on, many facts started to appear about the reality of the accusation. Now we need to know what terrorism means. What is the definition of terrorism? Terrorism is defined according to the Oxford Advanced Learners Dictionary (2000) "the use of violent action in order to achieve political aims or force the government to act" (Oxford Dictionary).

However, some organizations and countries have their own vision and definition of the word of terrorism. The FBI's definition of Terrorism in 2000-2005 report as "premeditated, politically motivated violence perpetrated against noncombatant targets by subnational groups or clandestine agents" (Herman, 694). Eventually, terrorism has been applied on all violence/violation actions all over the world whether in the past or present and the meaning of terrorism is expanded to include computer networks attacks (electronic war) that endeavor to cause serious damages to the countries interests or any other violent actions that lead to social, political, economical, psychological damages.

Islam and Muslims have been accused of terrorism and the western media highlighted and magnified the violent actions connected with Islam and Muslims while you might find unlimited violent actions led by non-Muslims, whether in the past or contemporary era, however, the western media pays no attention to what occurred nowadays (2017) in Myanmar, how Muslims are tortured, killed, displaced and burned alive, and the international community ignores their suffering and their misery because they are Muslim Minority in Myanmar. If Arakan Muslims, Rohinjya, start to defend themselves, they may be accused of terrorism. In contemporary age, another war was launched against Muslims in Bosnia and Herzegovina between 1992 and 1995. It was a war against Muslim minority in Bosnia in one of the horrible ethnic cleansing wars, "It was originally estimated that at least 200,000 people were killed and more than 2,000,000 displaced during the 1992-95 war. Subsequent studies, however, concluded that the death toll was actually about 100,000" (Britannica.com, Bosnian Conflict). It was the war that led a large number of Muslim women to be raped, mosques to be destroyed, hundreds of homes to be demolished. However, "The United Nations (UN) refused to intervene in the Bosnian conflict, but UN Protection Force (UNPROFOR) troops did facilitate the delivery of humanitarian aid" (Britannica. com, Bosnian Conflict). Muslim minority is exposed to ethnic cleansing over the world for no reason, only they are Muslims, indefensible and unspeakable.

The message of terrorism is to cause mass destruction to the place and the people. Almost the powerful ones make use of some countries, organizations and groups to lead the terrorist actions to fulfill the goals of the dominating powers in the world because such powers own fund, media, and decision-making. The weak ones may not lead terrorist actions without military and political support from the powerful ones. The minority becomes vulnerable and unspeakable; its voice may not reach out the international community. The mass media works for the benefit of the powerful party which owns the potentials and the control over such mass media. They may propagate the agenda that always serves their own interests.

\section{Terrorism Narration Overall the World}

\subsection{Terrorism, Islam and Politics}

The word of terrorism is mentioned in the Holy Quran just once in the form of a verb and that verb comes as a

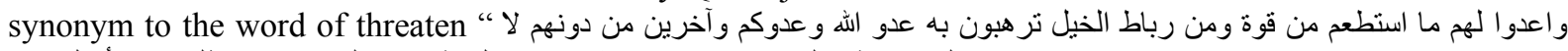

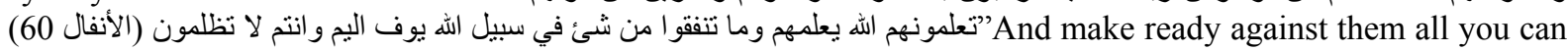
of power, including steeds of war (whatever) to threaten thereby the enemy of Allah and your enemy, and others besides them whom you may not know, (but) whom Allah does know. And whatever you shall spend in the Cause of Allah, shall be repaid to you, and you shall not be treated unjustly (Surah 8, Al-Anfal). The word of violence is not mentioned in the Holy Quran and the word of Forgiver is mentioned "91" and the word of "Merciful" is mentioned " 115 ".

The word of "terrify" comes to show the power to let the enemies dare not exceed the limits with Muslims if they see their power and capacity. It comes as a threat by showing the power that stops the enemies to take aggressive steps against Muslims, not by violent actions. This is the meaning of the word "terrify" which is mentioned once in the Holy Quran. Most of the Holy Quran Ayats tell us about mercy, tolerance, forgiveness, justice...etc. However, the west wants to attribute the word of terrorism to Islam and stigmatizes its followers with violence and terrorism. The truth is that Islam is the religion of mercy, tolerance, and respect for the others' beliefs and many Ayats call Muslims to treat the others with mercy, justice and tolerance.

Many terrorist actions that occurred in the world, the west attributed such terrorist actions to Muslims and Islamic countries. However, any terrorist action involved with non- Muslims, it may be attributed to psychic troubles as long as the perpetrator is white and non-Muslim. Two days ago, during writing this research, the random shooting in one of the concerts in Las Vegas, America, that led more than fifty to get killed but the 
politicians did not want to call that violent shooting a sort of terrorism because the killer is non-Muslim or he is not from the land of Islam. Las Vegas Sun Journal reported that "at least 59 dead, 527 injured on strip gunman takes his own life" and CNN reported that "he, the suspect, Stephen Paddock, 64, lived in a retirement community in Mesquite, Nevada, and his motive is unknown" CNN, Oct. 3. 2017. 6:11 am. EDT). This is one of the recent terrorist actions during writing this article. The western media treats such a killer and a terrorist as a suspect. "It happened during a country music festival on the Las Vegas Strip. The shooter shot from 32nd floor of Mandalay Bay Hotel" as reported by CNN.

Additionally, during working on this research, another shooting occurred yesterday, Sunday 6, November, 2017. $(\mathrm{CNN})$ stated "At least 26 people were killed in Sunday's church shooting in Sutherland Springs, Texas, Gov. Greg Abbott said at a press conference. About 20 others were wounded, said Freeman Martin, a regional director with the Texas Department of Public Safety, with victims ranging in age from 5 to 72 years old" By Dakin Andone, Kaylee Hartung and Darran Simon, CNN, November 6, 2017. The shooter has been identified as Devin Patrick Kelley, according to law enforcement sources. Regarding to the identity of the shooter, "Martin described the shooter in Sunday's press conference as a young white male who was dressed in all-black "tactical-type gear" and "wearing a ballistic vest" as reported by CNN. The Guardian reported that "At least 26 people are dead and 20 are injured after a gunman opened fire on a congregation at the First Baptist church in the small town of Sutherland Springs, Texas, on Sunday. 23 people died inside the church, two were found dead outside and one died on the way to hospital" (Monday 6 November, 2017). The official statement represented by Donald Trump, the president of America, the Guardian stated Trump's official reaction that "President Donald Trump, who is in Tokyo, has said the shooting was a "horrible crime" and an "act of evil." He blamed the suspect's "mental health problems" and said this was "not a guns situation" (Monday 6 November, 2017). If the shooter is a white and an American, the reasons definitely refer to health problems without giving sufficient time to the specialized channels or giving an opportunity to report the event due to the real investigations results, however, Trump's statement came fast to report that the reasons behind shooting were mental health problems, even the west may not categorize this attack as a terrorist attack. Such attacks would show the reader how the western media and politicians are prejudiced. Many stories of such terrorist attacks occurred in the past, particularly in America, but the media might not stress the stories of terrorism if such terrorist attacks were involved with non-Muslims.

The West likes to see Islam only in the places of worshipping as Mosques but they do not want to see Islam as a life order. The west starts to describe Islam with different attributions such as political Islam which endeavors to be a live incarnation of Muslims' lives. Sometime it gives Islam different descriptions as civilizing Islam in its best description and radical and extremist in its worse to let Muslims imitate the western civilization if they want to be civilized and Muslims need to avoid the strict rules of Islam if they like to see the civilizing Islam or moderate Islam in their lives. They like to see Islam just slogans and empty rituals that may not change life or lead the people to a better life. Islam is Islam from the era of Prophet Mohammed (PBUH) to present. No one may attribute Islam according the interests or goals he/she looks forward to. Motives and reasons behind hostility to Islam refer to that they look at Islam as a threat to the western civilization and they have created a sort of Islamophobia among their nations by portraying Islam as the only exporter of violence and terrorism to the West. The west escalated the war against Islam after the collapse of defunct Soviet Union, after the Cold War when the westerners realized the stronger faith that might invade their countries is Islam and their fear to become Europe Islamic in the near future; they prefer to fight terror/terrorism in the Islamic countries. They look at the immigrants as a danger and the westerners think that they may make Muslims dazzled with the western culture, civilization and then Muslim immigrants may be assimilated with the western cultures and ethics. However, the west finds Muslim Immigrants' faith in the hearts of its believers stable and you may not change their religion or identity, and it is not easy to wipe out the Islamic teachings from their daily life.

The policy makers in the west are not fair in their war against Islam and Muslims under the plea of terrorism and the readers see many of their people stand against their politicians because they may not deny that Islam is a life order competing with their earthly ideologies/projects. The west attempts to bring Islam out of its message to see civilizing Islam, moderate Islam, and political Islam that accord with their fancies and beliefs. Although Islam is a life order legislated by the Creator who recognizes well the needs of His creatures. The fear of Islam may be seen everywhere due to ongoing and organized campaigns against Islam and Muslim countries. The westerners look at Islamic awakening/resurgence a danger to their interests and they need to make that Islam only serve their interests in Islamic countries.

The westerners and their allies do not only launch a military war against Islamic countries in the name of war on terror, but they work on changing their thought, attitude and identity through secularism/secularization, globalism/globalization. They want to separate Islam from the state institutions. Islam should be excluded from 
civil life, education and politics. The west wants to see Islam only in the worshipping places as mosques and its values and teachings should be abandoned at the gates of the mosques. Muslim in the western view requires changing the sacred to secular, the local to global, and the particular to hybrid. It means to make Islam marginalized and separated from politics, educational policies and business dealings. The west managed to separate Christianity from its influence on the public life and keep Christianity just behind the walls of the church, however, this sort of separation between their religion and public life was easy in Christianity due to their injustice and underestimation of scientific facts and knowledge in general and it occurred due to what the church committed in the name of the Lord. Westerners initiated calling for individualism and autonomy, for secularism and secularization. There was a trend emerged towards secularization that protects their rights from the interference of the church. The west wants to repeat the same experience with Islam as a religion in spite of the entire differences between the two religions. There are many calls for secularization, globalization, hybridization, and westernization for all aspects of Muslim lives in the name of openness to the western civilization and coping with the movement of modernization. Arabs and Muslims may not catch up with the movement of development, only if they live a secular life, away of the power of Islam as claimed.

Moving to another technique to let the world scared of Islam. They stigmatize Islam with terrorism and violence to spread the concept of Islamophobia in the west and the world in general to destroy the commitment of Arabs and Muslims to Islam, taking advantage of the emergence of extremist/fanatic movements as Al Qaida and ISIS that tarnish the genuine image of Islam and Muslims, while such movements have been supported politically, financially and military from the great powers in the world to arouse hate and hatred in the hearts of the westerners and easterners alike to create fear of Islam. Many terrorist attacks occurred in the west, Muslims are in a position of accusation such Sep. 11, 2001, 11th March 2004 in Madrid, July 7th 2005 in London and other violent attacks.

However, Islamic worldview indicates that this universe comes into being as a result of the will of one Creator. That Creator WHO knows well what makes the life of a human being on earth possible and peaceful. Islam is the religion of submission only to one God. It is Allah Almighty. The call of Islam is the call for peace, good and rejects bad. After 9/11, terrorist attacks against Muslims have encouraged the fanatics in the United States and Europe to take more daring attacks against Muslims. Such attacks targeted Mosques, and other attacks targeted the Muslim themselves in streets and public places from anti-Islamic individuals who revenge from Muslims because they see Muslims as they are the exporters of terrorism to the west. Berkeley's Center for Race and Gender (CRG) reported that:

In 2015, there were 78 recorded incidents in which mosques were targeted; more incidents than ever reported in a single year since we began tracking these reports in 2009. Incidents in 2015 have more than tripled compared to the past two years in which there were only 22 mosque incidents reported in 2013 and 20 incidents in 2014. In fact, in both November and December of 2015, there were 17 mosque incidents reported during each of these months, numbers almost equivalent to an entire year's worth of reports from the previous two years. Additionally, 2015 saw the largest number of cases in both the Damage/Destruction/Vandalism category as well as the Intimidation category. (p. viii)

Behind the west war against Islam are political, cultural, social, and economic reasons. The westerners endeavor to dominate the Arab countries for their different sorts of wealth such as oil and other minerals. Simultaneously, their purpose is to create a people searching how to satisfy their lust and live with a faith that only practiced in the mosques on occasions as they restrict Christianity behind the walls of the church. Tramp pointed out in one of the Opera's programs before winning the American election that led him to the White House to be a president to America (YouTube) that the Gulf peoples live like kings and he gave example about the Kuwaiti citizens and he declared if he becomes a president of America, he will work hardly to return back that wealth of Arabs to the West. This is the reality of making conflicts and confrontations among the peoples of the Arab world.

Knudsen (2003) reported that the beginning of the political Islam as he claimed "the resurgence of Islam, now commonly referred to as a political Islam, is generally attributed to the crushing military defeats of Arabic countries suffered at the hand of Israeli forces in 1967" (qtd. in Milton-Edward, 2000, p. 123). However, the western countries do not realize that Islam contains the components of establishing a perfect state whether politically, economically, socially, religiously culturally...etc. from its beginning in Makkah when Quraish infidels understood that well. It is not a matter of a new religion that calls for worshipping One God in the mosque, however, Quraish infidels recognized well that religion might control everything in their life and by embracing that religion; it might change their policies, habits, beliefs and that new religion would dominate their entire lives. 
Consequently, Quraish and most of the Arab tribes stood strictly against that new religion because they recognized well it will be the voice that controls the different aspects of their lives. Perhaps it is date back to the period of prophet and his rightly guided Caliphs. Knudsen (2003) claimed that the Islamic revival started by establishing the Muslim Brotherhood which was founded in Egypt by Hassan Al Banna, 1926 and started to spread fast by appealing to Islam as a complete system and it will be a substitute to earthly western ideologies. Muslim Brotherhood has gained a large number of followers because it calls to the essence of Islam that makes Islam leads the world as a perfect system for Muslims' lives. It is not just a faith practiced in the mosque, but a life order that leads their life to better.

Islam followers, in the eyes of many Orientals and eastern/western countries, only want to rule and control the life aspects for political and personal objectives. In their view, Islam is not different from other ideologies made by philosophers and theorists who want to use their ideologies to rule and control the people. For such reasons, the westerners and Arab leaders see the political power of Islam as a threat to their thrones and interests which they endeavor to keep them to their familial dynasty. They see in Islam a political end and the Islamists arouse the passion of its followers to support them and help them to reach the ruling chair. Islam in such a way becomes a combination of belief and politics. This perspective is not desirable by the rulers and leaders of eastern/western countries. They see the arrival of Islamists to ruling chair the end of their secular life and awakening the correct teachings of Islam in the hearts of the peoples means the end of their thrones. The west may not allow any Islamic government in the Arab world to rule and regrettably the leaders of Arab world see in Islam a threat to their earthly interests. Therefore, they do not hesitate to help the west in fighting/ending the Islamic movements.

The inter/national community did not allow the Islamic movements to rule even if they reach to rule by the poll boxes as what occurred in Algeria, Turkey, Egypt, ...etc. In Algeria, the Sunni Islamic Salvation Front became a legal part in 1989 and gained the local elections in 1990 and the general election in 1992 and it was banned in two months of its winning because that political Islamic party called for Sharia, and glorified the Arabic Language and culture over the French ones that led to put an end to that Islamic party by sending their leaders to the jail. In addition, the global community conspired against Turkey recently to topple the ruling Islamic party under the leadership of Erodogan on 15 July 2016 and endeavored to topple the ruling Islamic party there to lead Turkey to secularism once again and let Islam only vacuum rituals and empty slogans practiced in the mosques and on occasions. The Guardian stated in 16 July, 2016 that "Erodogan said uprising had been carried out by a minority within military opposed to nation unity. He claimed some in the military had been taking orders from US-based- cleric Fathullah Gulen, and that the attempted Coup showed the Gullen was heading an armed terrorist organization. Gulen has denied involvement" (the Guardian, sat. 16 July 2016, 4:53 BST).

Later on, the Turkish regime has displayed the reality of the military coup which is ended by the power of the Turkish people who convene at public squares to protect the elected government and to keep democracy that has brought the Islamic party to rule in Turkey. Turkey pointed out that many countries involved in such conspiracy against Turkey regime and their mass media aired a false portrait about the reality of the situation in Turkey on the night of the failing military coup. Turkey has proved that the power of the people is the highest power that the military coup does not take it into consideration.

Another example of western/eastern conspiracy against Islamic governments in the Arab world and their determination to topple any Islamic government is Egypt under the rule of President Mohammed Morsi. Egypt's Islamic Party represented by the leadership of Mohamed Morsi who is a member of the Muslim Brotherhood Movement that ruled Egypt from 30 June 2012 to 3 July 2013 and the Army represented by Abdelfattah Al Sisi toppled his regime and sent him to the jail with many of Muslim Brotherhood followers. Morsi was elected through democratic poll observed by many local and global organizations that testified its fairness and legality, "But opponents complain that he (President Morsi) has not governed democratically or effectively and has been autocrat and incompetent" (the Guardian, Wednesday, 3 July, 2013). They did not remove him from ruling Egypt only but they also sent him to the court under the plea of many charges and then they convicted him of 20 years of hard work in April 2015, being guilty of torture and illegal detention of his opponents.

The International community initiates calling such movements over the world new Islamism, Islamic fundamentalism, Islamic radicalism, Islamic terrorism, and political Islam. It claims what Islamists call for today is not the core of Islam in the past. However, Islam in the past is the Islam of today. The enemies see Islam as a power that may control the different aspects of their lives and so that they do not stop their hostility to Islam. As the public repeats nowadays, Islamists want to bring a new Islam to their people. Terrorists/extremists become the stereotype of Arabs/Muslims and they have been accused by such stereotypes everywhere. If there is a terrorist attack in the world, the fingers of accusation may point to Muslims regardless of their race or origin. 
Islam calls for Jihad and this is the problem of the political Islam in the western world view. The west fears Jihad in Islam that would make the Islamists reach the power and impose the Islamic Sharia in all aspects of life. This is something the west may not approve. They do not want Islam to lead and to let Islam lead, this means more people will embrace Islam and more Islamic rituals will be enrooted in the hearts of its followers. By Islamic revival, the Islam power would prevail to control the globe.

Michael Flynn (2017) -RWW News (Available on You tube), the former American National Security Advisor claimed that "Islam is a cancer, a political ideology hiding behind a religion...just we face Nazism, Fascism, Imperialism, Communism, that is Islamism. It is a vicious cancer inside the body of 1.7 billion on this planet. It has to be excised. We should not fear this idea. We should define it clearly and go after it" (n. p). The makers of politics in America and the west in general declare their hostility to Islam; it is the ideology that millions of Muslims embrace in the world as they claimed. They do not like Islam and its legislations to prevail in the daily Muslims' lives. The west works hardly to create that Islam which suits them as claimed on varied occasions and that Islam does not rule but remains behind the walls of the mosques. It is not the matter of radical Islam as they claimed, it is the matter of Islam as Sharia that governs Muslims' lives and becomes part of Muslims' culture and identity.

\subsection{Terrorism, Islam and Mass Media}

The relationship between the west and the East, particularly Muslims and Arabs did not take a healthy stamp in the past. However, it started to take a turning point after September 11, 2001 attacks. Muslims become the target of America and its allies' in media and in real confrontations with the Islamic countries and organizations that support financially the radical Islam and terrorist attacks in the world as claimed. The escalation that started to find its way through their different mass media and social media encouraged the public to take more daring and aggressive attacks against Muslims in the west. Post 9/11, a lot of Muslims and Arabs have suffered from very aggressive verbal and physical attacks as if they are in charge of World Trade Centre attack. The western media concentrates on Muslims as the makers of terrorism and they portray Arab people wealthy and filthy. In fact, a lot of American public has no sufficient knowledge of Muslims' religion and culture, only from the media and movies which always depict Muslim and Arabs as anti-Americans, anti-Christian, anti-Zionism and makers of terrorism/troubles everywhere.

Said (1997) stated "Malicious generalizations about Islam have become the last acceptable form of denigration of foreign culture in the west what is said about the Muslim mind, or character, or religion, or culture as a whole cannot now be said in mainstream discussion about Africans, Jews, other Orientals, or Asians" (p. xiii). There is no clear vision or accurate information about Islam and Muslims in the west. The western media takes advantage of such terrorist actions to attribute to Muslims and arouses the hate and hatred against Islam and Muslims everywhere.

Many analysts, military men, public and reporters may not believe in the American report about September 11, 2001. You Tube is full of interviews that falsify the allegations of the west, particularly the official American report about the World Trade Center attack which the fingers of blame pointed to Muslims and Islam, only to fulfill political goals that arouse hostility to Islam and Muslims. Simultaneously, the west finds an opportunity to kindle the war against Islam/Muslims and put their hands on their wealth, and oil in particular. World Trade Centre may not be easily demolished by civilian planes and the theory of attack is scientifically justified by the experts and analysts to show the false allegations of the west.

The reader requires tracing You Tube reports and interviews of some analysts, reporters and military men, he may find a different story. Their words falsify American story regarding 9/11. Scientifically, the steel made of the towers, the style of collapse, the capacity of civilian planes to cause such mass destruction, all such things let you know the attack is a conspiracy to give the west and America in particular an excuse to strike Muslim countries and put their hands on their wealth in the name of confronting terrorism. If you want to recognize more about the truth, you may back to many titles of reports, interviews, and analysis in You Tube such as Who Was Really Behind the 9/11 Attack? Collapse: How the Towers Fell (2002), Tall length Documentary. Believe Your Own Eyes 9/11- No Planes. Was America Behind 9/11...etc. The readers may watch live reports, interviews, analysis and documentaries, definitely, they will change their belief concerning 9/11, 2001.

Most, if not all, mass media is dominated by the western power and they have directed their accusations of terrorism and hostility to Muslims. The image of Muslim and Islam become tarnished by the false/terrorist allegations of the western media. Media has been influenced by the western politics and their interests. Former U.S. Secretary of Sates, Lawrence Eagleburger stated on CNN, Sep. 11, "There is only one way to begin to deal with people like this, and that is you have to kill some of them even if they are not immediately directly involved 
in this thing" (FAIR, 2001, n. p.). Anti- Islamism movements start to appear whether by the individuals who stand against Muslims or as an organized behavior adopted by aggressive organizations to revenge from Muslims. The western media managed to arouse the anti-Islamic sentiment that became clear through repeated attacks against Muslims everywhere in America and Europe after 9/11, 2001. Funk and Said (2004) stated that:

Western images of Islam have long been based as much on imagination and presumption as on knowledge. In the Middle Ages, when the greatest threats to Christians were political anarchy or failure to live up to religious ideals, European Christian writers represented Islam as a force of chaotic and violent passions of the flesh...More recently, images of Islam have been shaped by the perception that Islamic culture represses women, encourages intolerant fundamentalism (a term that was originally associated with a twentieth-century Protestant movement in favor of literal Bible interpretation), and incites terrorism. (Islam and the West, p. 9)

The Arabs and Muslims condemned the western terrorist accusations of 9/11. Gentzkow, Jesse, and Shapiro (2004) pointed out in their report "In results we report below, 78 percent of respondents in seven Muslim countries said that they do not believe that a group of Arabs carried out the September 11, 2001, attacks on the World Trade Center" (Journal of Economic Perspectives, p. 117). Sanaa Alrifai (2015) stated in Review of History and Political Science, Vol. 3(1), June 2015 that "It is clear that the ancient and contemporary history has never witnessed an attack and distortion against a religion in this blunt vindictive way as Islam has suffered. However, Islam is still firmly standing in the minds and conscience of its believers" (p. 136) Although the stereotype of Muslims as terrorists, extremists, radicals, fundamentalists...etc and the western aggressive campaigns against Islam, Islam still spreads very fast in America and Europe and some of European capitals may become Islamic capitals within the coming fifty years. Consequently, Europe fights severely to keep the Islamic religion away of Europe by tarnishing the image of Islam in the hearts of Europeans and stigmatizing Islam and Muslims by terrorism and radicalism.

One of the western images of defamation of Islam and its prophet, it was the Danish cartoons in one of Danish Newspapers, Jyllands Posten, 2005, that devalued Islam and its prophet, such cartoons brought mockery on the prophet Mohammed's life and Sunnah which led the Islamic countries to call for boycotting the Danish commodities but that sort of sanctions did not stop their mockery. In 2008 a Danish film, Fitna, appeared to disparage Islam and its prophet, Mohammed (BPUH). Due to such defamation of Islam, the Islamic countries under Organization of Islamic Conference (OIC) have requested UN to criminalize defamation of religions in its conventions and rules to keep respect to Islamic identity and other religions. Berger (2010) stated that "while some Muslim resentment towards western action may be justified, the mixture of fact and fiction regarding west's doing vis-à-vis the Muslim world has also led to a great measure of self-pity and self-victimization among Muslims. This sentiment can be summarized by the words of former Malaysian prime Minister: Mahathir bin Mohamed "we are all Muslims, we are all oppressed, we are all being humiliated". (pp. 19-20).

Muslims during terrorist attacks, particularly 9/11, 2001 were one of the first groups who struggled to help the injured and did the best to help the different people regardless of their race, religion, or color. Many Americans had witnessed that some Muslims died attempting to help the injured people in 9/11 attack. Muslims felt their religious and social responsibility towards the citizens they share with them a lot of things as sharing the place they live in. However, the media in general and the western one in particular do not build the bridges of mutual understanding among multi religious communities but it starts to demolish any trust between the communities and Muslims. Western media works on spreading the phenomenon of Islamophobia, however, post 9/11, a lot of Europeans and Americans started to read more about Islam to be in contact with the contradictions they have seen/heard in their daily life about Muslims as terrorists and the Muslims' claim that their religion is the religion of peace and respect of other religions. As soon as they reach to the true image of Islam, they convert into Islam. The hostile campaigns against Islam bring a negative result. They let the westerners want to know more about Islam and Muslims, even those who had not paid any attention to Islam and Muslims before.

Many international organizations as UNESCO and some Islamic movements and organizations as (OIC) show their concern to create peace and mutual understanding through dialogues of cultures and religions to keep the social cohesion of the community whereas the makers of media go in different way to broaden the gap between cultures and religions, particularly, work on creating hostility to Islam and Muslims. Definitely, it is not only the Muslim community will suffer, but also the troubles may cover all segments of the world community regardless of their race, religion and to accuse Muslim of terrorism and simultaneously the world community ignores the others' terrorist actions that may lead the second targeted party to counter confrontation by other terrorist attacks.

Media supposes to bear a message to the world and endeavors to create tolerance and mutual understanding in 
the multi- religious and cultural community, but regrettably media has created a gloomy picture of Islam and Muslims that leads to more terrorist and violent actions against Muslims everywhere and the media does not bring the realistic situation in the countries in which Muslims are minority and exposed to daily torture and ethnic cleansing as what occurred in Arakan, Myanmar recently. Media message is to fight prejudice and discrimination whatever its color or race or religion. It requires calling for intercultural, political, and religious dialogues that create social coherence, political solidarity, and cultural understanding through strengthening the social, religious and cultural ties of the members of the community regardless of their race, religion and culture.

The international organizations and media need to exert their great efforts to enhance the healthy atmosphere and communication between different cultures, races, religions and lead the world to live in mutual respect, solidarity and coexistence through raising awareness about different religions cultures and races. Media needs to play a positive role to bring a sort of understanding between the opponents. Otherwise, confrontations among different races, religious sects, cultural groups, and political parties will prevail whether through mass media conflicts or military confrontations or community violence which may not keep any party. People require reading more about theological, historical, political, social, cultural interactions and implications of Islam, other religions and cultures to grasp accurate and clear image of Islam and Muslims, instead of creating hostility and darkening the image of Islam. Islam is a heaven message which bears all the components of worldview and the entire aspects of life. It is not an ideology or a philosophy made by talented people to run an aspect of life as political sphere. It is a global message, the message of the Creator, and it does not bear other interpretations as political Islam, radical Islam, fundamental Islam...etc. the essence of Islam is the same one from the era of Prophet Mohammed (PBUH) to the present days. It is the message of peace and prosperity for all the segments of the community regardless of their race and color. However, the west misinterprets this heaven message to achieve their dubious goals.

\section{Terrorism in Contemporary Narratives}

\subsection{Amy Waldman's The Submission (2011)}

Amy Waldman's The Submission (2011) tells us about the jury who is in charge of examining and selecting the best entries for 9/11 memorial. The Jury includes an artist (Pual Rubin), a representative of the Governor (Ariana Montagu), a representative of the Mayor (Geraldine Bitman), a representative of victims' families of that terrorist attack. The two contenders are submitted as blind submissions, one of them called "The Garden" advocated by Clair and the second one is "The Void" supported by Ariana. Eventually the winning submission is the Garden which is clearly designed by a Muslim architect; his name is Mohammed Khan, An American-born Indian.

In fact and fiction, the finger of terrorism has pointed to Arabs and Muslims. In Waldman's The Submission, the first suspects are Arabs and Muslims. Waldman's narrative reflects the reality of the situation and how the media will lead the public to believe in the western vision of the terrorist attack, the narrative states that "Edith called, sobbing "It's falling down, it's falling down," ... then a silence of Pompeian density so disturbing that Paul was grateful when Sami, his driver, broke it to say, "Oh sir, I hope it's not the Arabs," (researcher's emphasis) which of course it would turn out to be. Oh sir, I hope it's not the Arabs. Sami wasn't Arab, but he was Muslim" (p. 13). The reader may realize how the narrative reflects the reality when the western media has pointed the finger of accusation to Arabs and Muslims without giving the official investigations the sufficient time to report the facts about such event. Arabs and Muslims become suspects in the eyes of the western media. The statement ("Oh sir, I hope it's not the Arabs," indicates the terrorist attacks always are connected with Arabs and it implies that it is not the first time for Arabs to carry out such terrorist attacks.

However, if there is something good connected with Muslims, the western media attempts to hide. Amy will show how the jury may not expect the best entry designed by an American Muslim, a secular Muslim, but they show no satisfaction of his winning entry and his secularism may not help him to get approval of designing memorial easily. The Jury who represents the vision of the public may not imagine how a Muslim entry will win to be carried out as a memorial for 9/11. They want to keep the world remembers that the World Trade Center terrorist attack is planned and carried out by Muslims. Here in Amy narrative shows that "The piece of paper containing the winner's name was passed from palm to palm like a fragile folio. There were a few gasps and "hmmms," an "interesting," an "oh my." Then: "Jesus fucking Christ! It's a goddamn Muslim! "The paper had reached the governor's man" (p. 16). They do not want to see the Muslim entry winning and the name of Mohammed Khan as a Muslim to be immortalized in such memorial. "Each day brought more proof that the attackers were Muslims, seeking the martyr's straight shot to paradise" (p. 25). The public attitude is against Islam and Muslims, "The families will feel very offended. This is no time for multicultural pandering" (p. 17). The jury stands confused and helpless to solve this problem that may not be considered from the beginning and 
how may be solved, "What the fuck are we supposed to do?" (p. 17).

The jury has made the necessary investigation about the history of Mohammed Khan's family and his detailed resume, "but he had no known or identifiable link to any organization on the terrorist watch list...There was nothing to suggest he was an extremist. Anything but: he seemed all American, even in his ambition. "(p. 49). They do not find any suspicious work or clear violation for the law. However, the man seemed American in his identity and his ambitions. Muslims have lost their relatives as Asma, the illegal Bangladeshi woman who struggling to get compensation for her husband's death and immortalize his name in the memorial which is rejected by many anti-immigration groups who lead a protest in the city hall." "Respect for the law is what makes America, America," Sarge roared. "If we put illegals on the memorial, we will be spitting in the face of the law-abiding Americans, including legal immigrants, who died. The illegal immigrants who died came here seeking opportunity, but if they had stayed home they would still be alive. Isn't that the greatest opportunity of all?" (p. 77).

The issue of illegal aliens is very sensitive. Muslims in America after that terrorist attack attempted to help and volunteered to do the best as any Americans. They showed that Muslims in America want to live in peace, "But does America want to live in peace with Muslims?" (p. 79). This is the question. The painful events that Muslims live everyday/everywhere require many memorials to let the world remember the daily miseries of Muslims over the world. In Amy's The Submission, Ansar, who runs the foreign policy lobby states in challenging tone that:

Since we're talking about memorials, where is the memorial to the half million Iraqi children killed by U.S. sanctions? To the thousands of innocent Afghans killed in response to this attack, or the Iraqis killed on the pretext of responding to this attack? Or to all the Muslims slaughtered in Chechnya, or Kashmir, or Palestine, while the U.S. stood by? We keep hearing that it takes three hours to read the names of the dead from this attack. Do you know how long it would take to read the names of half a million dead Iraqi children? Twenty-one days. (pp. 79-80).

The abovementioned quote indicates how Muslims may remember their miseries over the world in the past or in the present. Their miseries need many memorials over the world. The Muslim victims in such mentioned countries find no one to show concern about their miseries. Many innocent Muslims have been killed for no reason only they are citizens in the countries accused of terrorism. Most of the victims are children and old men/women who may not escape easily from their destiny. The western countries, particularly America makes stereotypes of Muslims: terrorists, fundamentalists, radicals, extremists...etc, definitely Muslims over the world have their stereotypes of western countries. Violence may generate only violence. The terrorist movements may be found everywhere and in different colts and religions, but when the matter comes to Muslim, the media starts to magnify such works and easily attribute the terrorist attacks to Muslims.

Mohammed Khan here has proved his concern about terrorism and he wants to put his prints in such memorial. He shows his talents in architecture by designing the memorial "the Garden" which has got the admiration of the Juries. They wanted to let him presented by another name or by someone else to avoid rejection but his ideals, mannerisms and honesty which are known in his small community may not allow him. Mohammed Khan is a gifted Muslim who wants to share the American families, his people, their sorrows and miseries by designing such beautiful memorial. The jury could not find anything against him that might let them reject his design. In one way or another the media starts to publish headlines in daily journals about Islam which shows hostility to Islam "The problem with Islam is Islam," Alyssa Spier's column began, before describing, in retread language, the religion's violent propensities, its oppression of women, its incompatibility with democracy and the American way of life" (p. 109). They are many threats sent to Mohammed by different means of communications and through their marching protest "They held signs with by-now familiar slogans-NO MECCA IN MANHATTAN or STOP JI-HIDING" (p. 123). The role of media is essential particularly when the public in need for the truth they may not find easily. It may make the public stands for or against the issue discussed in the different channels of media.

Muslims have used the media to defend Mohammed Khan and showed the correct image of him. "An Architect, Not a Terrorist." In smaller print beneath it said: "Muslims like Mohammad Khan are proud to be American" (p. 172). In different situations, Mohammed Khan has confirmed his American identity more than his Islamic identity. He is one of the Americans, why do they want to cast doubts on his identity and his intentions. Many times, the people who are in charge of the memorial cast doubts on "The Garden", is it an Islamic Garden? Is it a Mohammadan Garden? Islamic phobia is revealed very early when the jury was very confused about reading the name of Mohammed Khan on the entry. American families are influenced by the western media and they see the responsibility of the towers attack lies upon Muslims. So that they do not want to see one of the Muslim 
memorials design wins the contest. The westerners become afraid of any Islamic manifestations or to hear the name of Muslims in their community. Islamophobia spreads in the western community rapidly and it was met by violence.

Muslims becomes after 9/11 in a position of suspicion. If the terrorist attack occurred over the world, the fingers of blame would be pointed to Muslim in spite of the repeated attacks against Muslims everywhere in the world. If they are not perpetrators to the terrorist attacks, they would be accused of supporting such terrorist attacks, "A lot of Muslims who would never commit terrorism still support it, for political reasons if not religious ones. Or they pretend it wasn't Muslims at all who did this". (270). The west keeps suspicious about Muslims as they are the perpetrators of the terrorist attack or at least they support it.

In Amy's narrative most of the violent/terrorist actions have been taken against Muslims in America. Many stories are published in the daily journals about repeated aggressions against Muslim women/ men in different states in USA in the name of anti-Muslim immigration groups, anti-Muslim organizations...etc. Asma Anwer is one of the Bangladeshi women in America who has lost her husband in the terrorist attack and she does not suppose to get compensation because she is an illegal immigrant, she attempts to support Mohammed Khan's memorial "The Garden". When she was stabbed, the people around her accused Muslims of her killing, "Debbie Dawson of SAFI was sure it was a Wahhabi offended by a woman playing a public role."See what they do to each other!" she kept saying on television Chaz was sure, with no basis in evidence, that it was a Bangladeshi jealous of Asma's money" (pp. 259-160). While Muslims have their own vision of the crime, "Muslim American Coordinating Council insisted that Asma had been slain by an Islamophobe. No, a xenophobe, insisted immigration reform activists" (p. 160). It is very clear, there is no trust between the two parties: the west and the Muslims. It is not easy to establish the bridges of trust while every party of them does not take closer steps towards the other. They want to push Mohammed Khan to withdraw his design from the memorial to put an end to such controversy of the memorial. However, such a controversy gives Mohammed Khan an opportunity to reach the world and brings to his architecture fame and peerless reputation.

\subsection{John Updike's Terrorist (2006)}

Updike's Terrorist narrates the story of Ahmad Ashmawi Mulloy whose Egyptian father, an immigrant, abandoned his Irish American mother at very early age, only three years. Ahmad has not got that good care and upbringing from the parents that give an opportunity to the others to control his life. Ahmad learns Arabic lessons and Islamic summons with Sheikh Rashid, a Yemeni imam of a small mosque in the neighborhood. Ahmad at that early age becomes easy target to be implanted in his mind whatever their tutors want him to learn. Sheikh Rashid teaches him how to avoid the vices of the American community and keeps following the Straight Path of the true believer that will lead him to happiness in his life and to the heaven hereafter.

Ahmad is very diligent in high school and attempts to avoid the confrontations with the bullies who always making troubles with students whose different color and race are unquestionable. To keep himself away of troubles, he does not pursue university study to keep his faith and mannerisms that may be spoiled in the university community. In fact, Ahmad is exposed, at that early age, to radical aspects of Islam by Sheikh Rashid that leads him to control Ahmad's life smoothly. Sheikh Rashid considers Ahmad's spiritual guide who recommends Ahmad to get a driving license to prepare him for a terrorist bombing in the future. He directs Ahmad to work in Lebanese furniture store owned by two brothers and run by one of their relatives, Charlie Chehab. Ahmad's life is run by Sheikh Rashid's orders. Chehab works on pushing Ahmad to attempt an illegal relationship with one of his school friends, Joryleen Grant. Later on, Ahmad will be informed that Chehab and Rashid belong to an Islamic cell planned for a serious attack on New York City and Ahmad's driving license has prepared him to such risky mission. Responding to Imam Rashid's teachings, Ahmad may sacrifice even his life to keep following the Straight Path, the path of martyrdom. Consequently, he will drive a bomb in the rush hour to Lincoln Tunnel to be exploded and caused mass destruction for place and people.

Jack Levy, New Prospect High School guidance counselor, attempts to persuade Ahmad to pursue his study in the college and he is the one who leads him to abort his terrorist attack. He is American Jew who deserted his religion and faith and becomes like Ahmad very critical to American culture and values. However, he does not want Ahmad to be involved in such terrorist attack that will put an end to his life. Ahmad understands late that Allah does not order him to kill the people and eventually he has aborted the terrorist mission and headed to New Jersey, Ahmad's home.

\subsubsection{Absence of Positive Family and Community Roles}

Ahmad Ashmawy does not find the care of the family in which his father abandoned his Irish mother when he was three years. At that critical age, Ahmad needs special orientation which may lead his future to better. 
However, his father's absence does not arouse the mother's passions to take more courageous role in raising her son. The parents are from different cultures, religions and languages. Ahmad does not know which one he needs to follow, his father's or mother's. He is torn between two cultures and religions. He decides to join the mosque to know more about the teachings of Islam. His mother has not given him sufficient time to recognize more about her son's friends and failings. Her work as a nurse in the hospital keeps her busy as well as her concern with painting that may not present something useful to her son, she addresses Levy explaining her paintings "I'm trying to work bigger, and brighter," "Life's so short, I suddenly figured, why keep fussing at the details? Perspective, shadows, fingernails - people don't notice, and your peers, the other painters, accuse you of being just an illustrator". The mother does not bother about her son's life, only her concerns with work and painting that will make her life brighter. Ahmad becomes an obedient student to Imam Rashid who makes use of Ahmad's critical age and steers his life to the direction he wants. Ahmad's life is reshaped by Imam Rashid's radical teachings which makes Ahmad afraid of the American community and culture that may drive him to lose his faith and religion.

In school, he endeavors to avoid confrontations with the trouble makers and he keeps his relationships with the others very limited. He does not want to pursue his study in the college fearing of losing his faith in that corrupt community as described by his spiritual guide, Imam Rashid. Imam Rashid does not set a good example to Ahmad but he wants to make use of Ahmad in carrying out terrorist bombings. Ahmad at that critical age, there is no family to follow his life or at least to take care of his daily activities. He becomes an easy victim to the extremists who see Islam from that dark perspective and they make use of the teenagers to carry out their satanic plans which are very far from the essence of Islam. Ahmad at the beginning does not hesitate to carry out the terrorist plans. However, his friend, Jack Levy has managed very late to change Ahmad's plan and persuaded him to stop bombing Lincoln tunnel to kill himself and American infidels.

Ahmad's loneliness and absence of the family role lead Ahmad to be directed by Imam Rashid and his Lebanese friends. Ahmad's faith leads him to follow the Straight Path depicted by Imam Rashid as the path of faith, sacrifice and martyrdom. The irony is that the Straight Path is not the straight path that Islam calls its followers to embrace. It is a deluding term that will lead Ahmad to victimize his life to show his determination to be on the Straight Path. Actually it is the path of the Satan; Islam does not ask Muslims to kill innocent people or to kill himself to prove that he is on the straight path. Some deluding Imams, as Rashid, see in Islam only how to achieve their political goals or their ideologies that fulfill their profits on the earth. They could not see the genuine essence of Islam that Islam which calls Muslims for coexistence, tolerance, mutual respect and love, even if such people are embraced other religions and values. However, some of Islamists misuse the word of Islam to help the enemies in distorting the image of Islam and let the enemies see in Islam only violence, extremism and terrorism, to become such terms stereotypes of Muslims and Islam.

\subsubsection{Arabs and Muslims' Stereotypes in the Narrative}

The west does not only misunderstand Islam or misinterpret it but also they have their own preconceptions of Islam that lead the west to believe in Islamophobia. Regrettably some Imams, Islamic Sheikhs, Islamic movements and Islamic leaders tarnish the name and the image of Islam by teaching radicalism, fundamentalism, extremism and terrorism which is not part of Islam or Sunnah of Prophet Mohammed (PBUH), who was known by tolerance, coexistence and mercy, even with his enemies. Islamic history requires to be read deeply and carefully to let the world have very accurate and clear vision of Islam. Regrettably, Islam becomes represented by hypocrites and naives who know from Islam only its name.

Updike's Terrorist may give the usual image of the west that the name of terrorism connected with Arabs and Muslims. Ahmad is a symbol of terrorism despite the writer's sympathy with Ahmad as an Arab-American Muslim, to depict Ahmad's misunderstanding to the teachings of Islam under the negative influence of Imam Rashid who does not present too much to Islam as he tarnishes the image of Islam in the minds of its followers. He becomes a tool of destruction to Islam more than to spread the culture of understanding, tolerance and love. However, some critics of Updike's Terrorist such as Christopher Hitchens in the Atlantic shows his dissatisfaction of the novel end for many reasons, one of such reasons is portraying Ahmad in the end as a nice person. They do not like such end for Ahmad as he represents Arab-American Muslims and Muslims in general. The title of the novel does not show a genuine terrorist at the end despite Ahmad's journey on the road of terrorism.

Imam Rashid's negative influence upon the life of Ahmad makes Ahmad look at the people from dark perspective. He looks at the people as devils who want to drag him away of the Straight Path and let him indulged into the materialistic life that reveals the bright manifestations of western civilization on surface and 
keep the dirty ones in deep:

Devils, Ahmad thinks. These devils seek to take away my God. All day long, at Central High School, girls sway and sneer and expose their soft bodies and alluring hair. Their bare bellies, adorned with shining navel studs and low-down purple tattoos, ask, what else is there to see? Boys strut and saunter along and look dead-eyed, indicating with their edgy killer gestures and careless scornful laughs that this world is all there is - a noisy varnished hall lined with metal lockers and having at its end a blank wall desecrated by graffiti and roller-painted over so often it feels to be coming closer by millimeters (p. 28).

The title reflects the western preconception of Arabs and Muslims "Terrorist", at the end the terrorist has not been a terrorist as Amy's The Submission shows Islamophobia in the hearts of the jury as soon as they see the name of Mohammed Khan on the list as a winner of the memorial design. The Arabs/Muslims' identity become in a position of suspicion in the contemporary era. Ahmad's Arabic name and the other Lebanese names have indicated how the west connects the terrorism and bombings only with Arabs and Muslims. Rashid as a Yemeni Imam also may indicate that his country is seen as an exporter of terrorism that leads American President, Trump, to issue resolutions to prevent Yemenis from entering the USA and other nationalities which are accused of terrorism. The fact is matching with the fiction in this narrative and in the first one, Amy Waldman's The Submission. There is a sort of harmony between the image of Islam in western reality and western narratives as the west likes to create hostility to Islam in both fact and fiction through their media or through their narratives which present stereotypes which are not very different from that of reality.

The irony is that the one who saves Ahmad's life from committing suicidal bombing is one of the American Jews who abandoned his faith and religion to live a secular life. The one who supposed to lead Ahmad to the Straight Path is his spiritual guide, Imam Rashid; however, he leads him to the wrong track that would bring him destruction and loss of his faith. Imam Rashid becomes a symbol of destruction that reflects misunderstanding of the essence of Islam, while the American Jew who appears without faith and religion portrayed as a savior to humanity. This is the materialistic look of the west to Islam as a destructive tool and the human without faith and religion becomes a symbol of salvation. Both Ahmad and Jack Levy have something in common, it is their hate and criticism to American culture but the first one could not coexist with such corrupting medium while the other would adapt himself to the materialistic world of the west. Levy also builds an illegal relationship with Ahmad's mother. The west requires Islam without spirit, that Islam does not interfere in the social, political, economical aspects of human life, that Islam is used only on Islamic occasions and for religious rituals. Islam should be treated as a life project, not only as a religious ritual that may be ended after leaving the worshipping places.

\subsection{Joel Rosenberg's The Last Jihad (2002)}

The Last Jihad addresses the story of Jon Bennett and Erin McCoy, who are in closed relationship with the president of America and they represent the strategists in Wall Street. They work on a secret project: oil project off the coast of Tel Aviv and Gaza Strip in two conflicting countries, Israel and Palestine. This project would be a source of enormous wealth for both countries. However, Joe and Erin could not anticipate the future. The terrorists have hijacked a jet plane into American city. Israeli investigations expect more serious attacks on Washington and New York that attacks drive America to lead a war on terrorism and mass destruction weapons in the Middle East as claimed.

The daily journals reported about the oil deposit discoveries in Palestine and Israel that may bring huge wealth to both countries "The Israelis and Palestinians were sitting on a gold mine" (p. 25). The media has played a main role in forming peoples' understanding and responding. Sometimes, the writers of fiction or real situations reports may be influenced by the media and they use the written or audio materials as good materials for their writing and acting. The Last Jihad is one of such narratives that rely basically on the media and politicians' reports and statements.

In fact, Times reporter Bill Orme wrote Arafat was "celebrating the multibillion dollar discovery of what industry officials confirmed is a major gas deposit" and telling people it would provide "a strong foundation for a Palestinian state." "This is a gift from our God to our people," Arafat told Orme, "to our children, to our women, to our people inside and outside, to our refugees and those who are living here on our land. (p. 24)

Rosenberg here writes about September 11 and how he evaluates the event. His narrative is not very different from the western media official reports which cast the blame upon Muslims. Most of the terrorist attacks in different places of the world are planned politically to distort the image of some nations and organizations, particularly, that ones with Islamic concerns or believe in Islam as a faith. Some fair analysts, reporters, and military men bring different visions based on real and scientific analysis of the 9/11 terrorist attack. The western 
media managed to persuade most of the public by the official reports. Here Rosenberg states in this narrative:

Until September 11, 2001. The day Islamic terrorists attacked New York and Washington. The day the Twin Towers fell and the Pentagon burned. The day three thousand Americans lost their lives. The day Palestinians began dancing in the streets. The day Osama bin Laden became a household name around the globe, and brought cheers throughout the Muslim world. The day President Bush declared a "war on terrorism." The day any prospect for Arab-Israeli peace and prosperity was mothballed, yet again. (p. 25).

The narrative attributed the terrorist attack to Muslims and Arabs who show their cheer and the spirit of revenge as the narrative claims "the day Palestinians began dancing...Osama bin Laden...brought cheers throughout the Muslim world", many Islamic countries contemned such terrorist attacks, but also some of American Muslims shared the Americans their sorrows and they attempted to do the best, being volunteers in helping the civilians in the buildings as other Americans. Their helping works have not been dragged attention to.

The reader may very early realize that the west in their nations and narrations accuse Arabs and Muslims of terrorism and violence. "Mohammed Jibril is a terrorist, Mr. Bennett. He lives in Moscow these days, working with various Islamic terrorist cells" (p. 60). The name mentioned is a name from Arabs and second remark "working with various Islamic terrorist cells"; Islam is mentioned as it is the generator of the terrorist actions. The western view of terrorism may not exceed the Islamic circle and Arabs as they are trouble makers and the exporter of violence and terrorism to the west. This narrative is a sort of of bad propaganda of Arabs, particularly, Iraq under Saddam Hussein rule," They've positively identified the Iraqi cell as the "four horsemen" (p. 64). Many terrorist attacks have occurred in the world, in particular, in the west and the finger of accusation points to Muslims and Arabs. The narrative exaggerates in portraying the terrorist attacks: American president is attacked, but he survives, another terrorist attack occurred in London but the queen is safe, the Canadian prime minister is injured in Paris bombings, 747 destroyed Saudi palace but the royal family escapes. Much horrible terrorist attacks in the narrative to show that terrorism is out of control and there are many terrorist attacks in different capitals of the west. The narrative likes to drag attention of the world, particularly the west to Muslims, as the west has been targeted by Islamic terrorist attacks. Such terrorist attacks will give the west a right to declare their war on terrorism, that terrorism which is seen only in Islamic countries or organizations. The west exerts its efforts to eradicate the re/source of terrorism whatever the price is as claimed.

On the other hand, Rosenberg states in The Last Jihad that they may establish peace and prosperity between the conflicting countries: Israel and Palestine through joint interests, through drilling oil that make each party gains a wealth that let them live peacefully, "a new world seemed possible - a world where Arabs and Israelis jointly drilled for oil, a world where two nations could become wealthy beyond belief, a world of prosperity leading to peace, of hope transcending hate, of freedom conquering fear" (p. 80). The idea of terrorism is taken a big echo in the western media to prepare the world to accept the next daring steps. The target is to topple the Iraqi regime to give space to Israel to carry out its agenda in the Middle East under the supporting and blessing of the west, particularly America as a leader to the actions taken against the Iraqi regime. The one who benefits from eradicating the Iraqi threat, it is Israel in the first place and Iran in the second one. They see in Saddam Hussein's regime a threat to their interests in the Middle East. "Come on, Joe. If you woke up a few months from now and Iraq was no longer a threat-just suppose - who benefits?" "Israel, I guess... We can wipe out terrorism and bring peace and prosperity to the modern Middle East" (p. 92). Now the irony is that you may not see peace and prosperity in the Middle East and Iraq in particular, but destruction and death.

In the narrative, Rosenberg quoted Saddam Hussein speech to destroy the Zionist enemies as the narrative claimed:

My Arab brothers, if we cannot recapture the glory of Palestine from the river to the sea, and from the sea to the river, with its crown Al-Quds, then we shall erase the Zionist invaders from the face of the earth. We will make the blood of the criminal Zionist invaders and occupiers run cold, and then cease to run at all. I have no intention but to do whatever pleases Allah and bestows glory onto our Arab Nation. Allah will not disappoint the Arab Nation, and we will triumph. Allah is the Greatest ... Allah is the Greatest ... Allah is the Greatest ... Let the imperialist and Zionist enemies of our Nation be debased ... May Allah damn the Jews. (p. 111).

The west attempts to present a concrete evidence that Iraq is in charge of the terrorist attacks of the twin towers, the White House, Pentagon, and Capitol Building to persuade the world that Iraq is the axis of evil with Iran and North Korea as Bush claimed "And it is our president who could certainly make the most persuasive case to the world that Iraq was a lethal, existential threat to world peace and prosperity" (p. 126). This is what the western media has presented to the world and their narratives, as this one, go in line with the media allegations of 
terrorism. The west moves for the benefit of Israel and Israelis may not stay calm when they see their interests in great threat. When they see the Iraqi nuclear reactor as a threat to their dominating power in the Middle East, they did not hesitate to destroy it at Osirik back in 1981 "without, I might add, giving us a head's up" (p. 128), as the narrative confirmed," and the Israelis will strike if we don't act fast" (p. 128).

The war on terrorism comes to protect the western interests in the world, particularly in the Middle East, and to excite Islam as Sharia, aspiring to run the world affairs secularly. The fast spread of Islam terrifies the politicians over the world and therefore they work on destroying Islam as they see it as a threat to their secular ideologies and their earthly interests. The west may not waste its time and money if they cannot find rewards from the business. It is not a matter of terrorism as it is a matter of interests and how to silence the projects that may harm their interests in the world. They work to get benefit from the rich countries in the Middle East to support their Treasury. Rosenberg here states in the narrative that "The lesson of Afghanistan was "don't fight a war you have no business winning" (the researcher's emphasis)" (p. 143).

The propaganda which has taken place in the western media and the western narrative that Iraq has mass destruction weapons and biological weapons that threaten its neighbors and the countries of the world. The end of the war exposed that there were no real threat from the military power of Iraq as it is a precautionary step from the west to protect Israel to be the only striking power in region and it is to protect the western interests in the Middle East. The Rosenberg's narrative comes to support the media allegations regarding the source of terrorism and to prove that Arabs and Muslims are the makers of violence and terrorism in the world to find a way to hit the Islamic countries and Islamic organizations which work on spreading Islam in the west. It is to arouse the passions of hate and hatred in the hearts of the west for two reasons: to let them fear Islam and simultaneously to support the western policies in their fighting against Islam. Saddam's regime and its invasion of Kuwait were a plea to strike Iraq and open the gate for Israel and Iran to achieve their targets in the regions. They have eventually destroyed the social solidarity in Iraq and other Arab world which revolted against their rulers under what they called The Arab Spring which was exposed to be the Arab autumn which came to destroy the social tissue and to transfer such countries to live under the line of poverty as in Yemen, Egypt and other countries, so called Arab Spring countries.

America has taken the Saddam's mass destruction weapons as a plea to launch a war against Iraq and other countries which support terrorism as they claimed. Passing days and after the Gulf war ended, there were no mass destructions weapons but that decision of war to destroy the potentials of one of the Arab countries power in the region. Iraq in this narrative is the first accuser of terrorism and demolishing the twin towers and other terrorist attacks over the world. However, such narratives come to stabilize the policies adopted by the west in their fighting of Islam under the cover of war on terrorism. The days proved that Saddam Hussein, the late president of Iraq, did not own mass destruction or biological weapons that were the justification of launching a war against Iraq, "not when I know that Saddam has nuclear weapons and anthrax and Sarin gas and VX ... not when I know Saddam is dying, desperate, hates us, and might think he has nothing to lose ... not when I know that our people could be slaughtered by the Butcher of Baghdad" (p. 143).

Their goals are summed up in the following quote. It is not only the matter of Israel, but also the matter of their interests. If the west feels their interests are in danger, they may use the nuclear weapons as in the past when they dropped that nuclear bomb on Nagasaki and Hiroshima. It will not be a surprise to use the mass destruction weapon to protect their interests in the Middle East and other parts of the world, "It will be to protect the lives and vital national interests of our people and our allies and to rid civilization of a mortal threat to its very survival" (pp. 144-145). What is forbidden/banned to be used by Saddam's regime, it becomes an option to be used by the American policies to put an end to the threats targeted them. In the narrative, the president gives his word to the Israeli Prime Minister, "You have my word: We are going to take down Saddam Hussein and neutralize his military machine no matter what it takes" (p. 146).

The narrative indicates the cooperative relationship between America and Israel and they work together to protect their interests in the region as the narrative indicated, "Their mission: To make sure Saddam Hussein never got a second chance at firing a nuclear missile at Israel or her neighbors" (p. 165). By such words, the reader may realize the harmony in the mutual interests between Israel and America. Both countries trade the investigative information through Mossad, FBI. CIA ...etc. and work together to keep their interests secured. The irony is that the title of the narrative (The Last Jihad) is taken from the name of the mission that requires to be fulfilled by Saddam's men. However, it brings an end to his life and his regime, "there was the crown jewel of the mission President Hussein now dubbed "The Last Jihad," history's final holy war against the Western and Zionist infidels" (p. 166). 
The narrative shows from the beginning that it relies on the media reports and the daily journals reports. This narrative comes influenced by the western media and attempts to stabilize their official reports about the terrorist attacks particularly that are tied with the twin towers attacks. The narrative mixes between the historical facts regarding some events and the fiction that attempts to justify the official reports declared on the media. It does not provide the reader with special concern to uncover the reality of the terrorist situation or at least to lead the reader to understand the genuine political situations, particularly, that one connected with terrorism, However, it shows its concern to support the political attitudes of the west to launch the war on terrorism which is seen only in connection with Islam and Arabs as this narrative claimed. From the other hand, the narrative published after the $9 / 11$ terrorist attack which most of the reporters and analysts cast doubts on its reality. Many evidences, interviews, reports, and analyses are videotaped in You Tube and other interviews in the TV. Channels or in the daily journals concerned about such topic falsify the west's allegations regarding $9 / 11$. At that time, the campaigns against Islam and Arabs were strong and the western media played a negative role to stabilize the thought that Muslims and Arabs were in charge of the terrorist attacks in the USA and other western countries. For this reason, this narrative may not present a real evaluation to counter terrorism as it work to stabilize the idea of Muslims and Arabs the makers of terrorism and terror, ignoring civilian victims who died in the name of war on terrorism. Simultaneously, this narrative spots the light on the collaborative work that may bring the two conflicting countries, Israel and Palestine to peace and prosperity through establishing joint projects as drilling oil in Tel Aviv and Gaza Strip.

\section{Conclusion}

The western media has its great influence in reshaping the public attitude about terrorism and the reasons behind. The post 9/11 terrorist attacks that demolished the World Trade Towers have created a negative attitude and tendency against Muslims and Arabs as the only one who were in charge of such terrorist attacks in 2001 as the western media and official statements claimed. Writing western narratives are influenced by the western media propaganda that has created anti-Muslims situations to give the west an excuse to strike Islamic countries involved with such terrorist attacks as the west claimed. The western narrative reflects the reality of their tendency to accuse Arabs and Muslims of terrorism. Rosenberg's Last Jihad, 2002, showed great influence with the western media and he used the daily journal reports as a material to his narrative that pointed the finger of blame and accusation to Muslims and Arabs, particularly Saddam Hussein's regime at that time before the Gulf war. Such allegation had given the west a golden opportunity to strike Iraq and destroy its potentials to create an endless chaos in the Middle East.

Rosenberg's narrative showed how Arabs conspire to kill the American president and Arabs run Islamic cells that work on destroying the western interests. This narrative portrays the Middle East, particularly Muslims and Iraqis, as the only exporter of terrorism to the west. Many Islamic groups and organizations are accused of terrorism in the narrative as Hamas, Hezbollah, Taliban, and Al Qaeda...etc. Iraq during the rule of Saddam Hussein was accused of gaining and threatening the world with mass destruction weapons. However, the Gulf war uncovered the false allegations of the west. Rosenberg's narrative was published in 2002, after 9/11 and the issue of terrorism was controversial. Writing of the narrative appeared influenced by the western media statements and official reports which cast blame on Muslims and Arabs, that gave the west a golden opportunity to strike Iraq and other Islamic organizations to protect its interests and Israel's in the Middle East, and to remain Israel the only striking power in the Middle East.

However, Updike's Terrorist was written in 2006. It comes to show a sort of fairness and sympathy with the Muslim/Arab character, to show that human being is influenced with the medium he lives in. Ahmad Ashmawy does not receive well raising or good familial relationship but he was left for the radical sheikhs to shape his character and direct him to commit a suicidal operation in the absence of the role of the parents and their follow-up in such critical age in which the boy's personality is shaped. Ahmad by the end responds to his friend's advice that reminds him that Allah does not ask the people to kill the innocents and Ahmad attempts to work out the real meaning of Islam in his mind. Then, he decides to stop bombing himself and returns to his home. This narrative comes to view the issue of terrorism from the reality of the situation in the community. It is to some extent, away of the media's influence. It shows the genuine Islamic spirit that makes Ahmad Ashmawy reject to kill innocents people when he listens to the voice of righteousness and conjures up the essence meaning of Islamic Dawah.

As the time passed after 9/11, the hidden facts of the terrorist attacks in 2001 and the controversial arguments of the analysts, reporters, politicians and official statements give sufficient space for the reality of terrorist attacks to appear. The western media and the official allegations are refuted by evidences that the daily journals, TV. Channels and reports have been revealed consecutively. Amy's The Submission, 2011, reveals the ugly face of 
the west to reject, at the beginning, the memorial design of Mohammed Khan for no clear reasons only that his name indicates that he is a Muslim. Eventually, his design wins the entry of memorial. The time of writing such narrative was sufficient to let the readers see the reality of the political situation regarding the terrorist attacks that demolish the twin towers. The narrative showed that the war on terrorism comes only to protect the western interests in the Middle East and to give sufficient space to the Israeli expansionist plans. The last Jihad, it is not only the name of Saddam's terrorist operation as the narrative claimed but it is the western dream to put an end to Saddam's regime and Islamic Jihad and they have succeeded to destroy Iraq and its potentials. The media has played a main role in creating Islamophobia in the west and put restrictions on Islamic countries and organizations to gain public support for their future plans which would target Muslims and Arabs as they are the makers of terrorism.

\section{References}

Abdullah, R. (2007). Islam, Jihad, and Terrorism in Post 9/11 Arabic Discussion Board. Journal of ComputerMediated Communication, 12(3), 15. https://doi.org/10.1111/j.1083-6101.2007.00363.x

Alrefai, S. (2015). History of Western Image of Islam and Muslim. Review of History and Political Sciences, 3(1), 135-142. https://doi.org/10.15640/rhps.v3n1a13

Berger, M. (2010). Religion and Islam in Contemporary International Relations. Clinjendael Diplomacy Paper. No. 27.

Britannica.com. Bosnian Conflict.

Dahinden, U., \& Koch, C., et al. (2011). Representation of Islam and Christianity in the Swiss Media. Journal Empirical Theology, 24, 197-202. https://doi.org/10.1163/157092511X603983

Funk, N., \& Said, A. A. (2004). Islam and the West Narrative of Conflict and Conflict Transformation. International Journal of Peace Studies, 9(1), (spring/summer).

Gentzkow, M., \& Sharpiro, J. (2004). Media, Education and Anti- Americanism in the Muslim World. Journal of Economic Perspectives, 8(3), 117-133. https://doi.org/10.1257/0895330042162313

Glenn, E. (2015). U. C. Berkeley Center for Race and Gender. Council on American-Islamic Relations.

Haque, F., \& Hossain, M. (2015). Global Media, Islamophobia and its Impact on Conflict Resolution. Institute Hazrat Mohammad (SAW), Dhaka, Bangladesh.

Herman, P. (2015). Terrorism and Critique of American Culture: John Updike's Terrorist. University of Chicago Press. https://doi.org/10.1086/679599

Jackson, L. (2010). Images of Islam in US Media and their Educational Implications. Educational Studies, 46, 3-24. https://doi.org/10.1080/00131940903480217

Jyllands Posten, 2005.

Knudsen, A. (2003). Political Islam in the Middle East. Chr. Michelson Institute, Norway.

Moore, K., Mason, P., \& Lewis, J. (2008). Images of Islam in UK. Cardiff School of Journalism, Media and Cultural Studies.

Qayyum, A., \& Mahmood, Z. (2015). Role of Social Media in the Light of Islamic Teaching. Al Qalem, 29.

Rosenberg, J. (2002). The Last Jihad. Tom Doherty Associates, LLC, New York.

Sahlaoui, M., \& Bouslama, N. (2016). Marketing Religion The Marketing and Islamic Points of View. American Journal of Industrial and Business Management, 6, 444-454. Scientific Research Publishing. https://doi.org/10.4236/ajibm.2016.64041

Said, E. (1997). Covering Islam: How the Media and the Experts Determine How We See the Rest of the World. New York: Vantage Books.

Salehnia, M. (2012). Political Zionism and Fiction: A Study of John Updike's Terrorist. Journal of Language Teaching and Research, 3(3), 484-488. https://doi.org/10.4304/jttr.3.3.484-488

Shadid, W., \& Koningsveld, P. (2002). The Negative Image of Islam and Muslim in the West: Causes and Solutions (pp. 174-196). Leuven, Peeters.

Smith, C. (2013). Anti- Islamic Sentiment and Media Framing during 9/11 Decade. Journal of Religion \& Society, 15. The Kripke Center.

Taqi-ud, D., Al. M., \& Khan, M. (2013). Holy Quran. Fahd King Glorious Qur'an Printing Complex, Madina, 
KSA.

The Guardian, Monday, 6 November, 2017.

The Guardian, Sat, 16 July 2016.

The Guardian, Wednesday, 3 July, 2013.

Updike, J. (2006). Terrorist. Alfred. A. Knope. New York.

Waldman, A. (2011). The Submission. Farrar, Straus and Giroux, New York.

Wehmeier, S. (2000). Oxford Advanced Learner's Dictionary. Oxford: Oxford University Press.

William, L. (2016). Islamic State Propaganda and the Main Stream Media. Lowy Institute for International Policy.

\section{Copyrights}

Copyright for this article is retained by the author(s), with first publication rights granted to the journal.

This is an open-access article distributed under the terms and conditions of the Creative Commons Attribution license (http://creativecommons.org/licenses/by/4.0/). 